\title{
The effect of transposable elements on phenotypic variation: insights from plants to humans
}

\author{
Liya $\mathrm{Wei}^{1} \&$ Xiaofeng $\mathrm{Cao}^{1,2^{*}}$ \\ ${ }^{I}$ State Key Laboratory of Plant Genomics and National Plant Gene Research Center (Beijing), CAS Center for Excellence in Molecular Plant \\ Sciences, Institute of Genetics and Developmental Biology, Chinese Academy of Sciences, Beijing 100101, China; \\ ${ }^{2}$ Collaborative Innovation Center of Genetics and Development, Fudan University, Shanghai 200433, China
}

Received November 12, 2015; accepted December 16, 2015; published online January 8, 2016

\begin{abstract}
Transposable elements (TEs), originally discovered in maize as controlling elements, are the main components of most eukaryotic genomes. TEs have been regarded as deleterious genomic parasites due to their ability to undergo massive amplification. However, TEs can regulate gene expression and alter phenotypes. Also, emerging findings demonstrate that TEs can establish and rewire gene regulatory networks by genetic and epigenetic mechanisms. In this review, we summarize the key roles of TEs in fine-tuning the regulation of gene expression leading to phenotypic plasticity in plants and humans, and the implications for adaption and natural selection.
\end{abstract}

transposable elements, gene expression, phenotypic variation

Citation: Wei, L., and Cao, X. (2016). The effect of transposable elements on phenotypic variation: insights from plants to humans. Sci China Life Sci 59, 24-37. doi: 10.1007/s11427-015-4993-2

\section{INTRODUCTION}

Transposable elements (TEs), or transposons, are DNA fragments that can move and integrate into new positions in the genome. Over a half-century ago, Barbara McClintock discovered TEs in maize (Zea mays), where they were regarded as "controlling elements" due to their effect on development, implying that TEs can affect the expression of host genes (McClintock, 1950, 1951). TE mobilization can also cause insertional mutations of a gene or inversions and translocations that rearrange genome organization and disrupt genome stability. Most organisms have evolved diverse epigenetic mechanisms to repress TE activity, including DNA methylation, histone modifications, and RNA interference (Cui and Cao, 2014; Lisch, 2009; Slotkin and Martienssen, 2007). Moreover, distinct epigenetic mechanisms control different classes of TEs, depending on their

*Corresponding author (email: xfcao@genetics.ac.cn) length, insertion time, and their local chromatin status (Cui et al., 2013; Ding et al., 2007; Yin et al., 2008; Zemach et al., 2013).

TEs are mainly divided into two classes according to their transposition mechanisms (Lisch, 2013; Slotkin and Martienssen, 2007). Class I TEs, known as retrotransposons, transpose by an RNA-mediated copy-and-paste mechanism; Class I TEs include long terminal repeat (LTR) retrotransposons and non-LTR retrotransposons. LTR retrotransposons include two superfamilies, Copia and Gypsy. Non-LTR retrotransposons are classified as long interspersed nuclear elements (LINEs) and short interspersed nuclear elements (SINEs). Class II TEs, also known as DNA transposons, transpose via a DNA-mediated cut-and-paste mechanism and include $h A T$ (hobo, Activator, and Tam3), CACTA, and Mutator-like element (MULE) superfamilies. These superfamilies of DNA TEs may derive to non-autonomous elements named miniature inverted-repeat transposable elements (MITEs), which are the 
highest copy-number TEs in rice (Jiang et al., 2004). Another type of DNA TEs is Helitrons, which transpose using a rolling-circle mechanism. Each class of TEs has autonomous and non-autonomous elements depending on whether they encode the necessary enzymes for transposition.

These different classes of TEs constitute the majority of genomic DNA in plants and are the most variable component of the plant genome. Genome size is closely associated with TE content in plants. Compared with the Arabidopsis thaliana genome, the rice (Oryza sativa) genome contains a higher proportion of repetitive sequences including TEs (Beló et al., 2008; Zhang, 2008). The maize (Zea mays) genome is about five times the size of the rice genome, due to a massive amplification of LTR retrotransposons (Tenaillon et al., 2010).

The distribution of TEs differs in different species. For example, most of the TEs in Arabidopsis are highly enriched in the centromere and pericentromere regions, whereas the TEs in rice and other plants with larger genomes are widely distributed along the chromosomes (Cheng et al., 2001; Fransz et al., 1998). Therefore, TEs and genes alternate in the genome, which increases the potential for TEs to influence the expression of nearby genes. In plants, TEs act as potential regulators of gene expression upon their insertion and transposition, intrinsic regulatory sequences, and epigenetic exaptation (Cui and Cao, 2014; Feschotte, 2008; Lisch, 2013). Several reviews have discussed the interaction between TEs and their hosts, and implicated TEs as natural mechanisms that can rewire the regulatory network of genes for host adaptation and evolution (Cordaux and Batzer, 2009; Levin and Moran, 2011; Lisch, 2013; Rebollo et al., 2012; Slotkin and Martienssen, 2007; Slotkin et al., 2012). In this review, we focus on summarizing the diverse examples of plant phenotypic variation caused by TE-mediated genetic and epigenetic regulation. We then give an overview of several studies describing the effect of TEs on phenotypic variation in humans. This emerging evidence indicates that plants and humans use TE-mediated mechanisms to adapt to the environment during evolution.

\section{TE-INDUCED INSERTIONAL MUTATIONS CAUSE PHENOTYPIC CHANGES IN HIGHER PLANTS}

A TE that inserts into the coding region of a gene will likely generate a null mutant allele by disrupting normal gene function (Figure 1A and Table 1). The first evidence for TE-induced null mutations was the unstable pigmentation patterns of maize kernels (McClintock, 1950) caused by insertion of the non-autonomous DNA TE Dissociation (Ds) (Feschotte et al., 2002; McClintock, 1950) at the $C$ locus, which encodes an enzyme for anthocyanin biosynthesis (Chen and Coe, 1977; McClintock, 1951). Ds insertion inactivates $C$, resulting in yellow kernels with a color- less aleurone (McClintock, 1950). In the presence of the autonomous transposon Activator (Ac), Ds can transpose and excise from the $C$ locus, restoring $C$ function and resulting in purple kernels with a colored aleurone. When $D s$ excision occurs in the germ cells, the whole kernel reverts to purple color; when $D s$ excision occurs in the somatic cells, the kernel has colored spots (McClintock, 1950, 1951). The timing and frequency of $D s$ excision give rise to variation in the size and intensity of colored spots in the kernels (Feschotte et al., 2002; McClintock, 1950).

Null mutations of anthocyanin biosynthesis genes caused by TE-induced insertion also occur in other plants. For example, $Y$ is the sorghum ortholog of maize $p 1$, which encodes a MYB-transcription factor and is required for biosynthesis of the red phlobaphene pigment in the grain pericarp (Chopra et al., 1999). A 23,018 bp CACTA family DNA transposon Candystripel (Csl) was the first active TE isolated in sorghum. Csl insertion into the second intron of $Y$ causes the color of the sorghum grain pericarp to change from red to variegated color. Cs 1 excision from $Y$ causes the pericarp to revert to red (Chopra et al., 1999). TE-mediated insertional mutations also cause alterations of seed coat color and flower color in Ipomoea purpurea (Clegg and Durbin, 2000; Park et al., 2007), changes in seed coat color in Brassica rapa (Li et al., 2012), changes in hull and internode color in rice (Hong et al., 2012), and differences in grape skin color (Kobayashi et al., 2004).

TE-induced insertional mutations not only cause unstable color phenotypes, but they can also alter traits related to starch content (Table 1). In maize, an Ac/Ds insertional mutation in the waxy $(w x)$ locus, which encodes a starch granule-bound glucosyl transferase for amylose synthesis in endosperm, led to lower amylose content (Wessler et al., 1986). Another example is Mendel's wrinkled-seed pea (Pisum sativum L.) controlled by the $r$ (rugosus) locus, which encodes an isoform of starch-branching enzyme gene (SBEI) (Bhattacharyya et al., 1990; Smith, 1988). In $r r$ lines, the inactivation of SBEI by insertion of an $A c / D s$ family TE causes less starch production and more sucrose in the embryo. These changes allow the seed to respond osmotic pressure, which produces the wrinkled seeds (Bhattacharyya et al., 1990). Moreover, analysis of 871 landraces of foxtail millet (Setaria italica) demonstrated that multiple TE insertions caused the diverse waxy varieties in this species in East and Southeast Asia (Kawase et al., 2005). All waxy or low-amylose landraces of foxtail millet carry weak or null mutations of GBSS1 (granule-bound starch synthase 1) induced by TE insertions that control the amylose content (Nakayama et al., 1998). The waxy phenotypes and the multiple independent insertions of TEs were selected during plant domestication and improvement (Kawase et al., 2005). Similarly, the GBSS genes also regulate different waxy traits in rice endosperm (Sano, 1984). A rice GBSS with an insertion of the LTR retrotransposon Dasheng causes the glutinous trait of rice 


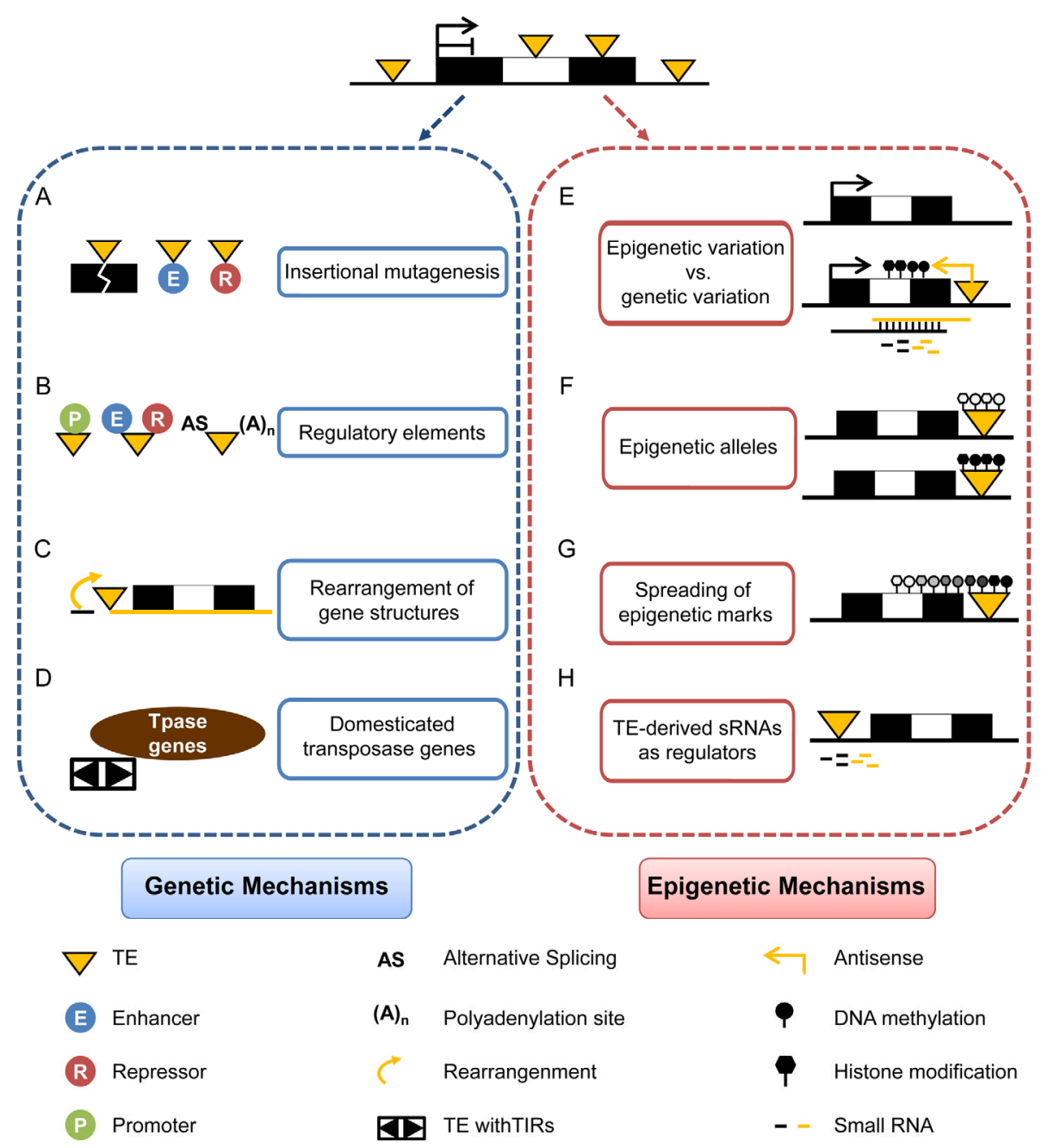

Figure 1 Transposable elements (TEs) regulate gene expression by genetic (A-D, blue box) or epigenetic mechanisms (E-H, red box). Black arrowheads represent transcription start sites. Rectangles represent exons (black), introns (white). Black lines indicate the upstream and downstream region of gene body.

seed in the Oragamochi cultivar (Hori et al., 2007). Taken together, these results show that TEs can confer diverse phenotypes upon insertion into different genes in various plants.

\section{NOVEL REGULATORY ELEMENTS ON TES CAUSE PHENOTYPIC VARIATION IN PLANTS}

In addition to interrupting gene expression to cause phenotypic changes, during evolution, some TEs acquire regulatory sequences such as transcription factor binding sites, transcription initiation site sequences, cis-elements that respond to environmental signals, alternative splicing sites, polyadenylation signals, and other regulatory sequences (Figure 1B and Table 1). Thus, TEs can introduce various regulatory elements to alter gene regulation and cause phenotypic changes in the host. For example, in the white chloroplast mutant of maize, insertion of a non-autonomous Mul TE into the 5' end of hcflo6 (high chlorophyll fluorescence 106) leads to a defect in chlorophyll biosynthesis
(Barkan et al., 1986; Martienssen et al., 1990). Interestingly, when the terminal inverted repeats (TIRs) of TE DNAs are heavily methylated, the inactive TE can drive expression of hcf106, acting as a cryptic promoter to revert the phenotype to wild type (Martienssen et al., 1990). Likewise, the LTR retrotransposon Renovator acts as a promoter to enhance expression of the rice blast resistance gene Pit, which confers broad-spectrum fungal resistance (Hayashi and Yoshida, 2009; Kiyosawa, 1972). The resistant rice cultivar K59 contains this TE insertion, but the susceptible cultivar Nipponbare does not (Hayashi and Yoshida, 2009). Therefore, TEs can function as promoters to activate gene expression and cause variation in plant phenotypes.

TEs can also act as long-distance enhancers to regulate gene expression and affect plant morphology. An elegant example in maize revealed long-distance regulation mediated by the LTR retrotransposon Hopscotch (Studer et al., 2011). Hopscotch is located $60 \mathrm{~kb}$ upstream of the domestication gene $t b l$ (teosinte branchedl) and it acts as a longdistance enhancer to increase $t b l$ transcription in maize. 
Table 1 Effect of TEs on phenotypic variation in plants ${ }^{\text {a) }}$

\begin{tabular}{|c|c|c|c|c|}
\hline $\begin{array}{l}\text { Regulatory } \\
\text { mechanism }\end{array}$ & TE classification & Regulated gene & Plant phenotypes & References \\
\hline \multirow{14}{*}{$\begin{array}{l}\text { Insertional } \\
\text { mutagenesis }\end{array}$} & *Class II, Ac/Ds & $C$ & $\begin{array}{l}\text { Variation in pigmentation pattern in maize } \\
\text { kernels }\end{array}$ & (McClintock, 1950) \\
\hline & *Class I, LTR, Dasheng & $\mathrm{OsCHI}$ & Rice gold hull and internode $(g h)$ mutants & (Hong et al., 2012) \\
\hline & ${ }^{*}$ Class II, CACTA superfamily, Cs 1 & $Y$ & Variegated pericarp in sorghum grain & (Chopra et al., 1999) \\
\hline & *Helitron & BrTT8 & Yellow seed coat in Brassica rapa & (Li et al., 2012) \\
\hline & *Class I and Class II & $C H S-D$ & Flower color variation in morning glory & $\begin{array}{l}\text { (Clegg and Durbin, 2000, } \\
\text { 2003) }\end{array}$ \\
\hline & *Class II, Mutator & bHLH2 & $\begin{array}{l}\text { Pale flowers and ivory seeds in Ipomoea } \\
\text { purpurea }\end{array}$ & (Park et al., 2007) \\
\hline & *Class I, Gypsy-type LTR, Gret1 & VvmbylA & Changes in grape skin color & (Kobayashi et al., 2004) \\
\hline & Class II, MITE & $F 3^{\prime} 5^{\prime} H$ & Changes in potato tuber skin color & (Momose et al., 2010) \\
\hline & Class I, LTR, dem1 & $M d P I$ & Parthenocarpic production of apple fruit & (Yao et al., 2001) \\
\hline & *Class II, Ac/Ds & $W x$ & Waxy kernels in maize & (Wessler et al., 1986) \\
\hline & *Class II, Ac/Ds & SBEI & Wrinkled-seed character in peas & (Bhattacharyya et al., 1990) \\
\hline & *Class I, LTR, Dasheng & GBSS & Glutinous rice seed in Oragamochi & (Hori et al., 2007) \\
\hline & Class II, $h A T$ family, $d T o k O$ & FON1 & $\begin{array}{l}\text { Multiple floral organs and numerous seeds in } \\
\text { rice }\end{array}$ & (Moon et al., 2006) \\
\hline & Class II, MuDR & ZmGE2 & $\begin{array}{l}\text { Increased embryo to endosperm ratio in } \\
\text { maize }\end{array}$ & (Zhang et al., 2012) \\
\hline \multirow{12}{*}{$\begin{array}{l}\text { Regulatory } \\
\text { elements }\end{array}$} & *Class II, Mul & Hcf106 & White sectors on maize leaves & (Martienssen et al., 1990) \\
\hline & Class II, Harbinger & $\operatorname{Pr}$ & Purple cauliflower & (Chiu et al., 2010) \\
\hline & Class I, retrotransposon & $b 1$ & Maize seed color & $\begin{array}{l}\text { (Selinger and Chandler, } \\
\text { 2001) }\end{array}$ \\
\hline & *Class I, LTR, Renovator & Pit & Blast resistance in rice & (Hayashi and Yoshida, 2009) \\
\hline & *Class I, Copia family, Hopscotch & $t b 1$ & Increased apical dominance in maize & (Studer et al., 2011) \\
\hline & ${ }^{*}$ Class II, hAT family, Hatvine1-rrm & $V v T F L 1 A$ & $\begin{array}{l}\text { Somatic variation in cluster shape in grape- } \\
\text { vine }\end{array}$ & (Fernandez et al., 2010) \\
\hline & Class II, MITE & Vgt1 & Flowering time in maize & (Salvi et al., 2007) \\
\hline & Class II, MITE & AltSB & Aluminum tolerance in sorghum & (Magalhaes et al., 2007) \\
\hline & *Class I, Copia-like & Ruby & $\begin{array}{l}\text { The accumulation of anthocyanins in blood } \\
\text { oranges }\end{array}$ & (Butelli et al., 2012) \\
\hline & *Class I, LTR & $W x$ & Waxy kernels in maize & (Varagona et al., 1992) \\
\hline & *Class I, Copia-like, COPIA-R7 & $R P P 7$ & Pathogen responses & $\begin{array}{l}\text { (Tsuchiya and Eulgem, } \\
\text { 2013) }\end{array}$ \\
\hline & *Class II, CACTA family & $F 3 H$ & Flower color and seed coat in soybean & $\begin{array}{l}\text { (Zabala and Vodkin, 2007; } \\
\text { Zabala and Vodkin, 2005) }\end{array}$ \\
\hline \multirow{3}{*}{$\begin{array}{l}\text { Rearrange- } \\
\text { ment of } \\
\text { gene struc- } \\
\text { tures }\end{array}$} & *Class II, $A c$ & $P-o o$ & Orange pericarp and cob in maize & (Zhang et al., 2006) \\
\hline & *Class I, Copia-like, Rider & SUN & Morphological variation of tomato fruit & (Xiao et al., 2008) \\
\hline & *Class II, hAT family,Tam3 & nivea (niv) & Petal color in Antirrhinum & $\begin{array}{l}\text { (Coen et al., 1986; Uchiyama } \\
\text { et al., 2013) }\end{array}$ \\
\hline \multirow{3}{*}{$\begin{array}{l}\text { Domesti- } \\
\text { cated trans- } \\
\text { posase } \\
\text { genes }\end{array}$} & *Class II, MULE & FHY3, FAR1 & Response to light signaling in Arabidopsis & (Lin et al., 2007) \\
\hline & *Class II, MULE & MUSTANG & Severe developmental defects in Arabidopsis & $\begin{array}{l}\text { (Cowan et al., 2005; } \\
\text { Joly-Lopez et al., 2012) }\end{array}$ \\
\hline & *Class II, $h A T$-like TE & DAYSLEEPER & $\begin{array}{l}\text { Essential for plant development in Arabidop- } \\
\text { sis }\end{array}$ & $\begin{array}{l}\text { (Bundock and Hooykaas, } \\
\text { 2005) }\end{array}$ \\
\hline \multirow{9}{*}{$\begin{array}{l}\text { Epigenetic } \\
\text { regulation }\end{array}$} & Class I, SINE & $F W A$ & Late-flowering in Arabidopsis & $\begin{array}{l}\text { (Fujimoto et al., 2008; } \\
\text { Kinoshita et al., 2007) }\end{array}$ \\
\hline & *Class II, MULE & $F L C$ & Late-flowering in Arabidopsis & (Liu et al., 2004) \\
\hline & *Class I, LINE & BONSAI & Severe dwarfing in Arabidopsis & $\begin{array}{l}\text { (Saze and Kakutani, 2007; } \\
\text { Saze et al., 2008) }\end{array}$ \\
\hline & Class II, $h A T$ family, $n$ Dart 1 & OsClpP5 & $\begin{array}{l}\text { Pale-yellow variegated leaves in rice seed- } \\
\text { lings }\end{array}$ & (Tsugane et al., 2006) \\
\hline & *Class II, $h A T$ family, Gyno- $h A T$ & $C m W I P 1$ & Sex determination in melon & (Martin et al., 2009) \\
\hline & ${ }^{*}$ Class I, Copia-like, SORE-1 & GmphyA2 & Photoperiod insensitivity in soybean. & (Kanazawa et al., 2009) \\
\hline & *Class II, CACTA & $\mathrm{ZmCCT}$ & Attenuated photoperiod sensitivity in maize & (Yang et al., 2013) \\
\hline & *Class I, SINE & $\operatorname{VTE3}(1)$ & Vitamin E accumulation in tomato fruits & (Quadrana et al., 2014) \\
\hline & *Class I, Copia-like, Sal-T1 & FAE1 & $\begin{array}{l}\text { Erucic contents in yellow mustard (Sinapis } \\
\text { alba) }\end{array}$ & (Zeng and Cheng, 2014) \\
\hline
\end{tabular}




\begin{tabular}{|c|c|c|c|c|}
\hline $\begin{array}{l}\text { Regulatory } \\
\text { mechanism }\end{array}$ & TE classification & Regulated gene & Plant phenotypes & References \\
\hline \multirow{7}{*}{$\begin{array}{l}\text { Epigenetic } \\
\text { regulation }\end{array}$} & ${ }^{*}$ Class I, Karma & $\mathrm{Eg} D E F 1$ & Mantled fruits in oil palm. & (Ong-Abdullah et al., 2015) \\
\hline & *Class I, LTR, Athila family & $U B P 1 b$ & Stress-sensitivity in Arabidopsis & (McCue et al., 2012) \\
\hline & *Class II, MITE & MAIF1 & $\begin{array}{l}\mathrm{ABA} \text { signaling and abiotic stress responses in } \\
\text { rice }\end{array}$ & (Yan et al., 2011) \\
\hline & *Class II, MITE, En/Spm-like & $\begin{array}{l}\text { CYP76M7, OsKSL7, } \\
\text { CYP99A3, OsCPS4, EUI }\end{array}$ & Plant height in rice & (Wei et al., 2014) \\
\hline & *Class II, MITE & OsGSR1, OsBR6ox & Leaf angle in rice & (Wei et al., 2014) \\
\hline & *Class II, MITE & ZmNAC111 & Natural variation in maize drought tolerance & (Mao et al., 2015) \\
\hline & *Class II, MITE & RAV6 & Leaf Angle and Seed Size in Rice & (Zhang et al., 2015b) \\
\hline
\end{tabular}

a) *: These examples are discussed in this review.

The $t b l$ gene encodes a member of the TCP family that represses branch growth and plays an important role in plant apical dominance (Cubas et al., 1999; Doebley et al., 1995). The increased expression of $t b l$ causes the increased apical dominance and repression of branching in maize compared with its wild progenitor teosinte, which has multiple, long branches (Studer et al., 2011). Thus, a long-distance enhancer in a TE mediates the branching architecture in modern maize. In grapevine, the hAT family TE Hatvine 1-rrm somatically transposed into the promoter region of VvTFL1A, activating VvTFL1A expression as a cis-acting enhancer (Fernandez et al., 2010). Overexpression of VVTFL1A, the closest homolog of Arabidopsis TERMINAL FLOWER 1 (TFL1) (Bradley et al., 1997), increases the inflorescence branching similar to transgenic Arabidopsis plants (Boss et al., 2006; Ratcliffe et al., 1998). Thus, somatic insertion of a $\mathrm{TE}$ in grapevine can alter the fruit-clustering phenotype (Fernandez et al., 2010), which may contribute to fruit yield. This study indicates that somatic transposition of TEs is important for plant breeding by tissue culture and rapid propagation (Huang et al., 2012).

TE sequences also can supply novel regulatory elements for plant responses to environmental signals. A striking example of a TE acting as a regulatory element in response to stress comes from the active MITE miniature ping (mPing) in rice (Jiang et al., 2003; Kikuchi et al., 2003; Nakazaki et al., 2003). A massive amplification of mPing occurred during prolonged tissue culture and rice domestication (Naito et al., 2006). During this amplification, mPing preferentially inserted into the $5^{\prime}$ flanking regions of genes and generated a new regulatory network for the response to cold, salt, and dehydration stresses (Naito et al., 2009). Several mPing-containing genes are up-regulated in response to environment signals, which form new stress-inducible alleles in rice (Naito et al., 2009). In addition, retrotransposons can control the cold-dependent accumulation of anthocyanin, which causes color formation in blood oranges (Butelli et al., 2012). For example, two retrotransposons, Copia-like retrotransposon Tcsl or its Solo-LTR, inserted in the upstream region of the Ruby gene. These TEs respond to cold treatment and activate expres- sion of the MYB transcription factor Ruby in Sicilian blood oranges. Similarly, in Chinese blood oranges, the Copia-like retrotransposon Tcs 2 inserted upstream of Ruby to trigger gene expression (Butelli et al., 2012). Upon cold-induction, the activation of Ruby increases anthocyanin biogenesis, giving rise to the darker color (Butelli et al., 2012).

In addition to acting in regulation at the transcriptional level, TE sequences also contain alternative splicing and polyadenylation signals that can influence gene expression at the post-transcriptional level. For example, in three $w x$ alleles, insertion of the LTR of a retrotransposon containing a splice donor and acceptor site induces novel alternative splicing patterns in the maize waxy gene (Varagona et al., 1992). Moreover, in soybean (Glycine max), the CACTA transposon Tgm-Express1 in intron two of the flavanone 3-hydroxylase gene $(F 3 H)$ generates diverse chimeric transcripts by alternative splicing, leading to lighter-colored flowers and seeds compared with wild type (Zabala and Vodkin, 2005, 2007). From genome-wide analysis, there are about $57 \%$ TE content in the diploid cotton, Gossypium raimondii (Wang et al., 2012). Although these TEs were found in only $2.9 \%$ of all G. raimondii introns, they confer up to $43 \%$ of the intron retention events and alteration of branch point-site, which contributed to intron retention-type alternative splicing events ( $\mathrm{Li}$ et al., 2014b). These findings from $G$. raimondii transcriptome further reveal that TE insertions can induce alternative splicing by genetic mechanisms. The retrotransposon COPIA-R7 controls expression of the disease resistance gene RPP7 (Resistance to Peronospora parasitica 7) by alternative polyadenylation in Arabidopsis (Tsuchiya and Eulgem, 2013). The COPIA-R7 element, which inserted in the first intron of $R P P 7$, introduces an alternative polyadenylation site from the TE LTRs to regulate pathogen responsiveness mediated by the critical balance between the functional and nonfunctional RPP7 transcripts (Tsuchiya and Eulgem, 2013). Thus, TEs can act as regulators of alternative polyadenylation, fine-tuning disease resistance genes and acting in the plant immune system (McDowell and Meyers, 2013). Taken together, these results show that when TEs transpose into the 5' ends, introns, or $3^{\prime}$ ends of genes, they can act as new promoters, 
enhancers/repressors, splice sites, and polyadenylation sites to alter gene expression and phenotypes (Figure 1B and Table 1).

\section{TE-INDUCED REARRANGEMENTS OF GENE STRUCTURE CAUSES PHENOTYPIC VARIATION}

Aberrant transposition events can rearrange gene architecture, causing sequence deletions, inversions, translocations, and duplications by homologous recombination. These rearrangements can produce a novel pattern of gene expression to create new phenotypes (Figure $1 \mathrm{C}$ and Table 1).

As expected, the colored phenotypic variants caused by TE-induced rearrangements were originally found in higher plants. The first example is the orange pericarp in maize by Ac element-induced chromosomal rearrangements (Zhang et al., 2006). The maize kernel pericarp red pigments are regulated by $p l$ gene encodes a Myb-homologous transcriptional regulator. The transposition of reversed $A c$ ends, which located in the intron of $p l$ and downstream of its paralog $p 2$ gene, can create a new functional chimeric gene $P$-oo and change the maize pericarp color (Zhang et al., 2006). In Antirrhinum, the chalcone synthase (CHS) gene nivea (niv) is responsible for flower color (Sommer and Saedler, 1986). In HAM5 lines, an inverted pair of autonomous Tam3 hAT family transposons resides up- and down-stream of the niv locus. The two Tam3 TEs may coordinately form a loop to attenuate the accessibility of transcription factors and further suppress niv expression, finally leading to white petals in HAM5 plants (Coen et al., 1986; Uchiyama et al., 2013).

Elongated tomato varieties, such as Roma, provide a striking example of TE-induced rearrangements altering gene regulation and plant phenotype. This shape change results from the rearrangement of IQDI2 (IQ domain 12), which controls fruit shape in tomato (van der Knaap et al., 2004; Xiao et al., 2008). Retrotransposition of the LTR retrotransposon Rider mediated this rearrangement, which brings IQD12 expression under the control of the fruit-specific $D E F L 1$ promoter. The new pattern of IQDI2 expression leads to the change in tomato fruit shape from round to elongated (Xiao et al., 2008).

\section{DOMESTICATED TE TRANSPOSASES CAUSE PHENOTYPIC VARIATION}

During plant evolution, the sequences encoding TE transposases, which mostly have DNA-binding domains, have likely been tamed many times as transcription factors to regulate gene expression and development (Figure 1D and Table 1). A few examples of TE domestication have been reported in plants. For example, Arabidopsis FHY3 (far-red-elongated hypocotyl 3) and FAR1 (far-red-impaired response 1) were co-opted from an ancient Mutator-like transposase (Lin et al., 2007). FHY3 and FAR1 can directly bind to the FBS (FHY3/FAR1 binding site) motif of the FHY1 (far-red-elongated hypocotyl 1) and FHL (FHY1-LIKE) promoters via the N-terminal zinc finger domain (Lin et al., 2007). FHY3 has an intrinsic transcriptional activation activity and it directly upregulates $F H Y 1$ and FHL to accumulate nuclear phyA (phytochrome A) for light responses (Hiltbrunner et al., 2006; Hiltbrunner et al., 2005; Lin et al., 2007). Meanwhile, phyA signaling downregulates FHY3 and FAR1. Thus, FHY3 and FAR1 act in a feedback loop that modulates phyA homeostasis (Lin et al., 2007). This study suggests that domesticated TE transposases can act as important regulators of plant responses to changes in the light environment.

Mutator-like transposases have also been exapted for MUSTANG genes in flowering plants. Mutations of Arabidopsis MUSTANG genes result in severe developmental and reproductive defects such as decreased plant size, delayed flowering, abnormal floral development, and reduced fertility (Cowan et al., 2005; Joly-Lopez et al., 2012). Other DNA TE transposases in the $h A T$ family have been domesticated in the transcription factor DAYSLEEPER, which can bind the Kubox1 motif and is essential for Arabidopsis development (Bundock and Hooykaas, 2005). In wheat and barley, the Gary gene was derived from a $h A T$-like transposase but Gary function remains largely unknown (Muehlbauer et al., 2006). As more plant genomes are sequenced, more proteins from TE domestication will be identified and their functions will be elucidated. Taken together, these emerging results indicate that the coding sequences of TEs are domesticated for acquisition of gene function, often in DNA binding or transcription, which produces novel gene regulation patterns for host phenotypic diversity.

\section{TES AFFECT PHENOTYPIC VARIATION BY EPIGENETIC MECHANISMS}

\section{TE-mediated epigenetic variation vs. genetic variation}

Some TE-mediated epigenetic variation has a genetic basis. A TE located downstream of a gene may produce an antisense transcript that forms double-stranded RNAs and subsequently 24-nt small RNAs. These 24-nt small RNAs may direct local de novo DNA methylation and histone H3K9 di-methylation for silencing of the sense gene (Figure 1E). For example, Arabidopsis Col (Columbia) plants have a LINE element downstream of the BONSAI gene but Cvi ecotype plants do not. In $d d m 1$ (decrease in DNA methylation 1) mutants, de-repression of the LINE element in Col produced antisense transcripts and 24-nt small RNAs, causing spreading of DNA methylation, BONSAI silencing, and a dwarf phenotype (Saze and Kakutani, 2007; Saze et al., 2008). By contrast, Cvi, which lacks the TE insertion, did 
not produce detectable $d d m l$-induced small RNAs and de novo DNA methylation (Saze and Kakutani, 2007). Therefore, the presence or absence of the TE at the $3^{\prime}$ end of $B O N S A I$ provides a good example of epigenetic variation that depends on a genetic alteration.

Based on the presence, position, and types of TEs, different Arabidopsis ecotypes have distinct natural variants of FLC (Gazzani et al., 2003; Long et al., 2013; Michaels et al., 2003; Zhai et al., 2008). Ler (Landsberg erecta) plants have a MULE-type DNA transposon in the first intron of FLC and this TE has the $\mathrm{H} 3 \mathrm{~K} 9 \mathrm{me} 2$ repressive mark and produces 24-nt small interfering RNAs (siRNAs). Therefore, the TE negatively regulates $F L C$ expression in cis, resulting in early flowering in Ler (Gazzani et al., 2003; Liu et al., 2004; Michaels et al., 2003). However, in the Col background, FLC expresses to higher levels than it does in Ler, as Col lacks the MULE insertion (Liu et al., 2004; Zhai et al., 2008). Based on such genetic variation, small RNA-directed epigenetic variation between Ler and Col contributes to the differences of flowering time (Liu et al., 2004; Zhai et al., 2008). Thus, TE-mediated genetic and epigenetic mechanisms can cooperatively regulate a nearby gene.

TE-mediated genetic changes that cause epigenetic variation can also respond to environmental conditions. This mechanism can rapidly generate variation to allow the host to adapt to growth in different geographical regions, especially during crop improvement. Soybean and maize are two short-day plants, which have evolved photoperiod insensitivity in cultivars via TE insertion. This ensures flowering and seed setting of short-day crops grown under long-day conditions. For instance, soybean GmphyA2 encodes phytochrome A (phyA) (Liu et al., 2008). In soybean, insertion of the Copia-like retrotransposon SORE-1 causes hypermethylation and reduced expression of GmphyA2. Accessions containing SORE-1, including many grown at high latitudes, are insensitive to photoperiod and thus well adapted to growth under long-day conditions (Kanazawa et al., 2009). In maize, insertion of a CACTA-like TE within the $Z m C C T$ promoter epigenetically regulates photoperiod sensitivity and may have helped accelerate the spread of maize to long-day regions (Yang et al., 2013). In maize, the early-flowering inbred lines have high DNA methylation levels of a 5,122-bp CACTA-like TE inserted in the upstream region of $Z m C C T$; this represses ZmCCT transcription, attenuating photoperiod sensitivity for adaptation to longer days, similar to its rice homolog Ghd7 (Xue et al., 2008; Yang et al., 2013). However, the maize ancestor teosinte, which only flowers in short-day conditions, lacks the CACTA-like TE insertion. Thus, this TE insertion may have enabled maize to spread from tropical to temperate zones (Yang et al., 2013). Such TE-induced epigenetic changes largely depend on genetic alterations, which may have significance for plant environmental adaptation and evolution.

\section{TE-induced epigenetic alleles}

Epigenetic alleles ("epialleles") do not result from changes in the DNA sequence, but show heritable phenotypic variation caused by different epigenetic states (Figure 1F). Recent reports provide direct evidence of TE-induced epialleles in the determination of nutrition-related agronomic traits in plants. Naturally occurring epialleles determine the highly valuable nutritional trait of vitamin E (VTE) content in tomato fruits (Quadrana et al., 2014). The expression level of vitamin $E 3(1)$, which encodes an enzyme involved in the biosynthesis of vitamin $E$, modulates the vitamin $E$ contents. In natural tomato populations, DNA methylation in the vitamin $E$ 3(1) promoter region can be spontaneously reverted, resulting in different epialleles that affect vitamin $E$ content in eight tomato Andean landraces (Solanum lycopersicum), three commercial reference cultivars (also $S$. lycopersicum), and the wild species $S$. pimpinellifolium (LA1589) and S. habrochaites (LA407) (Quadrana et al., 2014). Differentially expressed vitamin E 3(1) alleles are associated with differences in siRNA profiles and DNA methylation status of a SINE retrotransposon in the promoter region of vitamin E 3(1) (Quadrana et al., 2014). Similarly, multi-allelic variation in the expression of FATTY ACID ELONGATION1 (FAE1) controls erucic acid contents in yellow mustard (Sinapis alba) (Zeng and Cheng, 2014). The $F A E 1$ alleles $E^{l}, E^{2}, E^{3}$, and $e$ show a range of $F A E 1$ expression and erucic acid contents (Javidfar and Cheng, 2013). The insertion of the Copia-like retrotransposon Sal-T1 in the 5' UTR of FAE1 in the $E^{2}$ and $E^{3}$ alleles decreased $F A E 1$ transcription, leading to a reduction in erucic acid contents. Moreover, compared with the $E^{2}$ allele, $E^{3}$ acts as an epiallele, having even lower levels of mRNA and erucic acid contents due to higher DNA methylation levels in the promoter region of FAE1. The null allele $e$ resulted from an insertional mutation in the coding region of $F A E 1$ by a 3,100 bp PIF/Harbinger-like DNA TE, causing zero erucic contents (Zeng and Cheng, 2014).

Recent work described a fascinating example of TE-induced epigenetic alleles, the Karma-mediated epiallele of $\operatorname{Eg} D E F 1$, which causes the defective "mantled" trait in vegetative propagation of oil palm (Elaeis guineensis) cultivars (Ong-Abdullah et al., 2015). EgDEF1 encodes a MADS-box transcription factor essential for the formation of flower organs, like its ortholog, Arabidopsis APETALA3 (AP3) (Adam et al., 2007). In normal fruits, the Karma insertion at the intron of $\mathrm{Eg} D E F 1$ is hypermethylated (Good Karma) and EgDEF1 produces full-length transcripts. By contrast, hypomethylated Karma (Bad Karma) mediates alternative splicing of $\mathrm{Eg} D E F 1$ to yield truncated transcripts responsible for the mantled-fruit phenotype (Ong-Abdullah et al., 2015). Therefore, weeding out plants carrying the Bad Karma epiallele at the plantlet stage provides an effective means to improve oil palm yield (Ong-Abdullah et al., 2015; Paszkowski, 2015). The interplay between alternative 
splicing and DNA methylation reveals another mechanism for regulating gene expression and phenotypic variation in plants.

For a TE located near a host gene, the repressive epigenetic marks that silence the TE can spread to the adjacent gene and eliminate or attenuate its expression, possibly generating an epiallele (Figure 1G). For example, a $h A T$ family TE inserted downstream of the melon gene CmWIPI induces DNA methylation spreading to the CmWIPI promoter and reducing CmWIPl transcription (Martin et al., 2009). CmWIPl encodes a $\mathrm{C} 2 \mathrm{H} 2$ zinc-finger transcription factor, which expresses in the carpel primordium to inhibit the development of female organs (Martin et al., 2009). The epigenetic changes mediated by the effect of the TE on expression of CmWIPl leads to the transition from male to female flowers in gynoecious lines (Martin et al., 2009).

\section{TE-derived small RNAs act as regulators in cis or trans}

Many TE sequences generate siRNAs that fine-tune gene expression in cis or trans (Figure $1 \mathrm{H}$ ). In rice, the MITE-derived 24-nt siR441 and siR446 function as positive regulators of abscisic acid signaling and abiotic stress responses by repressing their target, MAIF1 (miRNAs regulated and abiotic stress induced F-box gene) (Yan et al., 2011). In Arabidopsis, the transcripts of Athila LTR retrotransposons produce double-stranded RNAs that are then processed into 21- and 22-nt siRNAs. One of these Athila-derived siRNAs, siRNA854, targets the 3'UTR of OLIGOURIDYLATE BINDING PROTEIN $1 B$ (UBPIb) and negatively regulates it at the post-transcriptional and translational levels (McCue et al., 2012). The repression of the $U P B I b$ mRNA mimics the $u b p l b$ mutant stress-sensitive phenotype, influencing the host stress response (McCue et al., 2012; McCue and Slotkin, 2012).

Additionally, genome-wide analysis of the targets of siRNAs produced by DCL3a (Dicer-like 3a) in rice demonstrated that TE-derived 24-nt siRNAs affect expression of nearby genes to alter important agricultural traits (Wei et al., 2014). Loss of DCL3a-dependent 24-nt siRNAs caused a reduction of $\mathrm{H} 3 \mathrm{~K} 9 \mathrm{me} 2$ modification, up-regulation of nearby genes, and affected on homeostasis of the plant hormones gibberellin and brassinosteroid. This, in turn, affected plant height and leaf angles (Wei et al., 2014). Recently, an epiallele of Epi-rav6 was identified, which caused by hypomethylation of a MTIE at the 5 ' regions of RELATED TO ABSCISIC ACID INSENSITIVE3 (ABI3)/VIVIPAROUS1 (VPI) 6 (RAV6) in rice (Zhang et al., $2015 \mathrm{~b})$. The ectopic expression of BR homeostasis-related gene affects rice leaf angle in MITE-induced Epi-rav6 mutants by similar epigenetic mechanisms. Likewise, in maize, a recent study demonstrated that a MITE is associated with natural variation in drought tolerance and the insertion of this MITE in the ZmNAC111 promoter represses gene expression via RNA-directed DNA methylation (Mao et al., 2015). The overexpression of ZmNAC111 enhanced drought tolerance in Arabidopsis and maize seedlings (Mao et al., 2015), as did its rice homolog OsNAC1O (Jeong et al., 2010). This MITE insertion seems to have occured after maize domestication, because it is commonly found in temperate germplasm, but less frequently found in tropical germplasm, indicating that it has been adopted for drought tolerance during maize breeding (Mao et al., 2015).

Plants commonly produce polyploids during evolution and TE-induced epigenetic effects also affect genome dominance in polyploid plants. For example, TE-derived 24-nt siRNAs can silence recessive subgenomes in hexaploid Brassica rapa (Woodhouse et al., 2014). The dominant subgenomes have fewer TEs and tend to express more genes (Woodhouse et al., 2014). Also, domesticated cotton, Gossypium hirsutum (AADD tetraploid), derived from hybridization of the ancestral species, Gossypium arboreum (AA diploid) and Gossypium raimondii (DD diploid) genomes were completely sequenced (Li et al., 2015; Li et al., 2014a; Wang et al., 2012; Zhang et al., 2015a). Comparative genomic analysis found that TEs from the D subgenome are more actively transcribed than TEs from the A subgenome ( $\mathrm{Li}$ et al., 2015). The A subgenome also has higher proportions of copia-type retrotransposons adjacent to coding genes ( $\mathrm{Li}$ et al., 2015). Among above three cotton species, the fiber yield and quality vary significantly (Wang et al., 2016). The cultivated allotetraploid cottons produce longer and better fibers than its two diploid ancestors. Further, it is found that TEs may regulate unbalanced expression pattern of some important genes involved in fiber development from two cotton subgenomes. For examples, a copia-type retrotransposon and a LINE retrotransposon located at the promoter of the MYB-domain transcription factor $(M Y B)$ and ethylene response factor (ERF) gene, respectively, and they both enhanced the transcription of nearby gene, which plays key role in cotton fiber development (Wang et al., 2016).

Thus, TE-derived small RNAs negatively affect gene expression and are important for regulating genome dominance in plant polyploids.

\section{TE-DERIVED TRANSCRIPTION FACTOR BINDING SITES CAN REWIRE REGULATORY NETWORKS}

In addition to affecting genomic dominance in cotton, TEs can also alter the gene regulatory networks by producing or eliminating transcription factor binding sites (TFBS). For example, in the $G$. hirsutum A subgenome, the DNA transposon Tgml in the CesA3-4 (cellulose synthase A 3-4) promoter and a MITE deletion in the UER2-2 (UDP-4-keto6-deoxy-d-glucose 3,5-epimerase 4-reductase) promoters increased the numbers of pyrimidine boxes or conserved MYC- and MYB-binding sites in these key promoters, which may contribute to the strong expression of CesA3-4 and UER2-2 during cotton fiber growth (Li et al., 2015). 
The expansion of TEs can also create TFBS in large and complex genomes such as that of humans (Feschotte, 2008). For example, on average $20 \%$ of TFBS are associated with TEs in human embryonic stem cells (Kunarso et al., 2010). Furthermore, many TFBS derived from TEs are epigenetically regulated by DNA methylation, which has important implications for tissue-specific gene functions in humans (Xie et al., 2013). This indicates that TEs can mutate or introduce TFBS to shape new gene regulatory networks (Figure 2). However, since fewer TFBS have been identified in plants, examples of TE-derived TFBS from plants remain rare. With innovations in high-throughput sequencing, more TE-derived TFBS will be tested for their effects on gene regulation and phenotypic variation in plants.

\section{TES AFFECT PHENOTYPE DIVERSITY IN HUMANS}

Insights from pioneering studies of TEs in plants, and accumulating evidence from studies in animals, highlight the role of TEs in human disease, genetic diversity, and genome evolution (Cordaux and Batzer, 2009; Erwin et al., 2014; Hancks and Kazazian, 2012; Kaer and Speek, 2013; Lander et al., 2001; Rebollo et al., 2012; Singh et al., 2014). DNA sequences from TEs make up approximately $45 \%$ of the human genome and include mostly non-LTR retrotransposons such as the active, autonomous element LINE1 (L1, $16.9 \%)$, and the nonautonomous elements SINEs Alu (10.6\%) and SINE-VNTR-Alu (SVA, 0.2\%) (Cordaux and Batzer, 2009; Lander et al., 2001). Currently, about 80-100 active L1 remain competent to retrotranspose in humans; these L1s drive the mobilization of Alu and SVA elements (Cordaux and Batzer, 2009; Levin and Moran, 2011).

De novo retrotransposition can harm human health. For example, in 1988, Kazazian et al. showed that L1-mediated

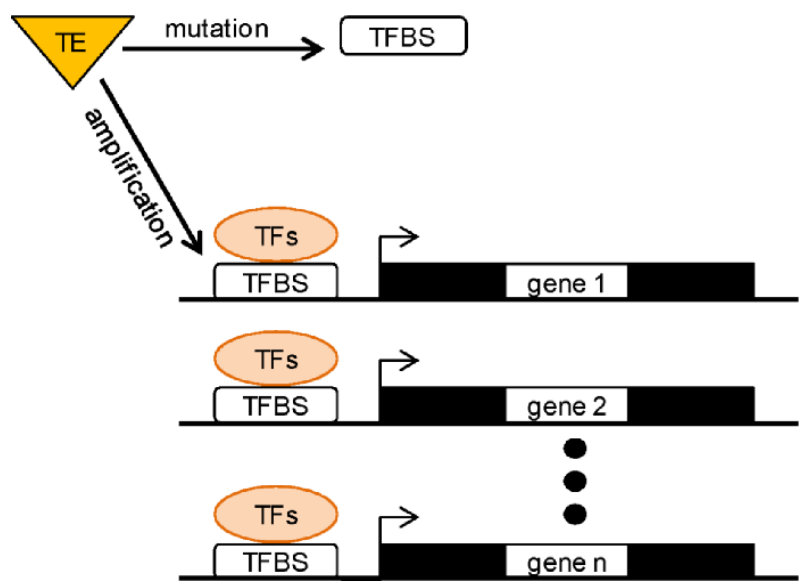

Figure 2 Transposable elements (TEs) shape gene regulatory networks by modifying transcription factor binding sites (TFBS). The yellow triangle represents a TE. Rounded rectangles represent TFBS. Orange ellipses represent transcription factors. Black rectangles represent exons and white rectangles represent introns of genes. Black lines indicate the upstream and downstream regions of the gene. The arrowhead represents the transcription start site. retrotransposition events caused hemophilia A by insertion of a TE in exon 14 of the gene encoding Factor VIII (Kazazian et al., 1988). Subsequently, researchers identified 101 diseases, including neurofibromatosis, muscular dystrophy, diabetes, choroideremia, and cancer, that resulted from de novo retrotransposition events, including $25 \mathrm{L1}$ insertions, 61 Alu insertions, 10 SVA insertions, 4 L1 poly(A) sequence transductions, and 1 processed pseudogene (Hancks and Kazazian, 2012; Kaer and Speek, 2013; Singh et al., 2014). Although the functional evidence for retrotransposon insertions in human diseases remains limited, these insertions may serve as novel biomarkers to help diagnosis (Singh et al., 2014). In addition, growing evidence demonstrates that misregulation of retrotransposition in the nervous system can cause neurological disorders such as Rett syndrome and schizophrenia, suggesting that TEs play important roles in neurogenesis (Erwin et al., 2014). In addition, recent studies showed that the longevity protein SIRT6 links L1 retrotransposition and aging; during aging, the multiple defense systems regulating L1 retrotransposition become weaker, leading to activation of L1 in somatic tissues and causing age-associated pathologies such as cancer and neurodegeneration (Van Meter et al., 2014).

Beyond harmful effects, retrotransposon insertions also benefit their host by creating diversity, which also can rewire gene regulatory networks via genetic and epigenetic mechanisms similar to those described in plants. Some retrotransposons carry cis-elements that can act as sensors of environmental changes; therefore, their transcription and transposition activities change in response to environmental signals and hormones in the brain and in disease (Erwin et al., 2014; Rebollo et al., 2012). Also, retrotransposons are generally repressed by diverse epigenetic modifications, which are dynamically modulated in different environments to rapidly rewire gene regulation for individual survival. Thus, TEs plays vital roles in the plasticity and adaptability to environmental changes throughout the human lifespan (Erwin et al., 2014; Rebollo et al., 2012). This supports Barbara McClintock's genome shock hypothesis in plants, which states that environmental challenges induce TE mobility to generate genetic or epigenetic diversity for host survival (McClintock, 1984; Wessler, 1996).

\section{OUTLOOK}

TEs are important sources of genetic and epigenetic variation and have important effects on gene regulation and plant phenotypic variation. TE-mediated gene regulation plays much broader roles in organisms with complex TE-rich genomes, particularly in humans and in crops such as rice and maize. Genome-wide analyses of the effects of TE-induced changes in crop species (specifically polyploids) and in humans are only beginning to be explored. Dealing with TE sequences in large, complex genomes remains challenging, owing to their high copy numbers, which can result in hun- 
dreds of matches for short reads produced by many highthroughput sequencing methods. However, the emergence of new, long-read deep-sequencing technologies may help us to analyze TE transposition events and explore the mobilome, that is, the complete picture of TE mobility within a species. Rapid advances in studies of mobilomes, epigenomes, transcriptomes, and phenomics, will advance our understanding of the functional relationships of TEs, gene expression, and phenotypic variation.

A particularly interesting question remains how TEmediated genetic and epigenetic variation contributes to plant and human adaption in response to environmental changes. New somatic and germline insertions of TEs in response to environmental challenges can alter gene expression. The phenotypic variation caused by somatic insertions only occurs in a subset of somatic cells that will not be transmitted to the next generation. However, somatic phenotypic variation can be inherited in plants that use vegetative reproduction. Through selection, beneficial variations from germline insertions can remain by across generations, providing a new approach for plant breeding and human adaptation. Current, limited evidence from plants and humans indicates that TEs can quickly amplify themselves and act as regulators to influence phenotypes in response to environmental challenges, which is reminiscent of the Lamarckian acquisition hypothesis (Martienssen, 2008). Emerging research has just started to exploit TE-mediated genetic and epigenetic inheritance of acquired traits for plant breeding and human health.

Bursts of TE activity may generate epialleles by changing epigenetic modifications. How many epiallele-based traits were selected during plant domestication remains unknown. In addition, it will be very important to know how many TEs recycled as TFBS in plant and human genomes contributed to build new gene regulatory networks for phenotypic plasticity. This research will substantially expand the lists of TEs that contribute to phenotypic plasticity in plants and humans. Moreover, such emerging research will likely reveal additional novel mechanisms by which TEs affect phenotypic plasticity.

Compliance and ethics The author(s) declare that they have no conflict of interest.

Acknowledgements This work was supported by the National Natural Science Foundation of China (31210103901, 31123007), the National Basic Research Program of China (2013CB835200), and the State Key Laboratory of Plant Genomics (2015B0129-01). Liya Wei was supported by the China Postdoctoral Science Foundation (2015M570170).

Adam, H., Jouannic, S., Orieux, Y., Morcillo, F., Richaud, F., Duval, Y., and Tregear, J.W. (2007). Functional characterization of MADS box genes involved in the determination of oil palm flower structure. J Exp Bot 58, 1245-1259.

Barkan, A., Miles, D., and Taylor, W.C. (1986). Chloroplast gene expres- sion in nuclear, photosynthetic mutants of maize. EMBO $\mathrm{J} 5$, 1421-1427.

Beló, A., Nobuta, K., Venu, R.C., Janardhanan, P., Wang, G.L., and Meyers, B. (2008). Transposable element regulation in rice and Arabidopsis: diverse patterns of active expression and siRNA-mediated silencing. Tropical Plant Biol 1, 72-84.

Bhattacharyya, M.K., Smith, A.M., Ellis, T.H., Hedley, C., and Martin, C. (1990). The wrinkled-seed character of pea described by Mendel is caused by a transposon-like insertion in a gene encoding starch-branching enzyme. Cell 60, 115-122.

Boss, P.K., Sreekantan, L., and Thomas, M.R. (2006). A grapevine TFL1 homologue can delay flowering and alter floral development when overexpressed in heterologous species. Funct Plant Biol 33, 31-41.

Bradley, D., Ratcliffe, O., Vincent, C., Carpenter, R., and Coen, E. (1997). Inflorescence commitment and architecture in Arabidopsis. Science 275, 80-83.

Bundock, P., and Hooykaas, P. (2005). An Arabidopsis hAT-like transposase is essential for plant development. Nature 436, 282-284.

Butelli, E., Licciardello, C., Zhang, Y., Liu, J., Mackay, S., Bailey, P., Reforgiato-Recupero, G., and Martin, C. (2012). Retrotransposons control fruit-specific, cold-dependent accumulation of anthocyanins in blood oranges. Plant Cell 24, 1242-1255.

Chen, S.M., and Coe, E.H., Jr. (1977). Control of anthocyanin synthesis by the $\mathrm{C}$ locus in maize. Biochem Genet 15, 333-346.

Cheng, Z., Buell, C.R., Wing, R.A., Gu, M., and Jiang, J. (2001). Toward a cytological characterization of the rice genome. Genome Res 11, 2133-2141.

Chiu, L.W., Zhou, X., Burke, S., Wu, X., Prior, R.L., and Li, L. (2010). The purple cauliflower arises from activation of a MYB transcription factor. Plant Physiol 154, 1470-1480.

Chopra, S., Brendel, V., Zhang, J., Axtell, J.D., and Peterson, T. (1999). Molecular characterization of a mutable pigmentation phenotype and isolation of the first active transposable element from Sorghum bicolor. Proc Natl Acad Sci USA 96, 15330-15335.

Clegg, M.T., and Durbin, M.L. (2000). Flower color variation: a model for the experimental study of evolution. Proc Natl Acad Sci USA 97, 7016-7023.

Clegg, M.T., and Durbin, M.L. (2003). Tracing floral adaptations from ecology to molecules. Nat Rev Genet 4, 206-215.

Coen, E.S., Carpenter, R., and Martin, C. (1986). Transposable elements generate novel spatial patterns of gene expression in Antirrhinum majus. Cell 47, 285-296.

Cordaux, R., and Batzer, M.A. (2009). The impact of retrotransposons on human genome evolution. Nat Rev Genet 10, 691-703.

Cowan, R.K., Hoen, D.R., Schoen, D.J., and Bureau, T.E. (2005). MUSTANG is a novel family of domesticated transposase genes found in diverse angiosperms. Mol Biol Evol 22, 2084-2089.

Cubas, P., Lauter, N., Doebley, J., and Coen, E. (1999). The TCP domain: a motif found in proteins regulating plant growth and development. Plant J 18, 215-222.

Cui, X., and Cao, X. (2014). Epigenetic regulation and functional exaptation of transposable elements in higher plants. Curr Opin Plant Biol 21c, 83-88.

Cui, X., Jin, P., Cui, X., Gu, L., Lu, Z., Xue, Y., Wei, L., Qi, J., Song, X., Luo, M., An, G., and Cao, X. (2013). Control of transposon activity by a histone H3K4 demethylase in rice. Proc Natl Acad Sci USA 110, 1953-1958.

Ding, Y., Wang, X., Su, L., Zhai, J., Cao, S., Zhang, D., Liu, C., Bi, Y., Qian, Q., Cheng, Z., Chu, C., and Cao, X. (2007). SDG714, a histone H3K9 methyltransferase, is involved in Tos17 DNA methylation and transposition in rice. Plant Cell 19, 9-22.

Doebley, J., Stec, A., and Gustus, C. (1995). Teosinte branched1 and the origin of maize: evidence for epistasis and the evolution of dominance. Genetics 141, 333-346.

Erwin, J.A., Marchetto, M.C., and Gage, F.H. (2014). Mobile DNA elements in the generation of diversity and complexity in the brain. Nat Rev Neurosci 15, 497-506. 
Fernandez, L., Torregrosa, L., Segura, V., Bouquet, A., and Martinez-Zapater, J.M. (2010). Transposon-induced gene activation as a mechanism generating cluster shape somatic variation in grapevine. Plant J 61, 545-557.

Feschotte, C. (2008). Transposable elements and the evolution of regulatory networks. Nat Rev Genet 9, 397-405.

Feschotte, C., Jiang, N., and Wessler, S.R. (2002). Plant transposable elements: where genetics meets genomics. Nat Rev Genet 3, 329-341.

Fransz, P., Armstrong, S., Alonso-Blanco, C., Fischer, T.C., Torres-Ruiz, R.A., and Jones, G. (1998). Cytogenetics for the model system Arabidopsis thaliana. Plant J 13, 867-876.

Fujimoto, R., Kinoshita, Y., Kawabe, A., Kinoshita, T., Takashima, K., Nordborg, M., Nasrallah, M.E., Shimizu, K.K., Kudoh, H., and Kakutani, T. (2008). Evolution and control of imprinted FWA genes in the genus Arabidopsis. PLoS Genet 4, e1000048.

Gazzani, S., Gendall, A.R., Lister, C., and Dean, C. (2003). Analysis of the molecular basis of flowering time variation in Arabidopsis accessions. Plant Physiol 132, 1107-1114.

Hancks, D.C., and Kazazian, H.H., Jr. (2012). Active human retrotransposons: variation and disease. Curr Opin Genet Dev 22, 191-203.

Hayashi, K., and Yoshida, H. (2009). Refunctionalization of the ancient rice blast disease resistance gene Pit by the recruitment of a retrotransposon as a promoter. Plant J 57, 413-425.

Hiltbrunner, A., Tscheuschler, A., Viczian, A., Kunkel, T., Kircher, S., and Schafer, E. (2006). FHY1 and FHL act together to mediate nuclear accumulation of the phytochrome A photoreceptor. Plant Cell Physiol 47, 1023-1034.

Hiltbrunner, A., Viczian, A., Bury, E., Tscheuschler, A., Kircher, S., Toth, R., Honsberger, A., Nagy, F., Fankhauser, C., and Schafer, E. (2005). Nuclear accumulation of the phytochrome A photoreceptor requires FHY1. Curr Biol 15, 2125-2130.

Hong, L., Qian, Q., Tang, D., Wang, K., Li, M., and Cheng, Z. (2012). A mutation in the rice chalcone isomerase gene causes the golden hull and internode 1 phenotype. Planta 236, 141-151.

Hori, Y., Fujimoto, R., Sato, Y., and Nishio, T. (2007). A novel wx mutation caused by insertion of a retrotransposon-like sequence in a glutinous cultivar of rice (Oryza sativa). Theor Appl Genet 115, 217-224.

Huang, C.R., Burns, K.H., and Boeke, J.D. (2012). Active transposition in genomes. Annu Rev Genet 46, 651-675.

Javidfar, F., and Cheng, B. (2013). Single locus, multiallelic inheritance of erucic acid content and linkage mapping of gene in yellow mustard. Crop Sci 53, 825-832.

Jeong, J.S., Kim, Y.S., Baek, K.H., Jung, H., Ha, S.H., Do Choi, Y., Kim, M., Reuzeau, C., and Kim, J.K. (2010). Root-specific expression of OsNAC10 improves drought tolerance and grain yield in rice under field drought conditions. Plant Physiol 153, 185-197.

Jiang, N., Bao, Z., Zhang, X., Hirochika, H., Eddy, S.R., McCouch, S.R., and Wessler, S.R. (2003). An active DNA transposon family in rice. Nature 421, 163-167.

Jiang, N., Feschotte, C., Zhang, X., and Wessler, S.R. (2004). Using rice to understand the origin and amplification of miniature inverted repeat transposable elements (MITEs). Curr Opin Plant Biol 7, 115-119.

Joly-Lopez, Z., Forczek, E., Hoen, D.R., Juretic, N., and Bureau, T.E. (2012). A gene family derived from transposable elements during early angiosperm evolution has reproductive fitness benefits in Arabidopsis thaliana. PLoS Genet 8, e1002931.

Kaer, K., and Speek, M. (2013). Retroelements in human disease. Gene 518, 231-241.

Kanazawa, A., Liu, B., Kong, F., Arase, S., and Abe, J. (2009). Adaptive evolution involving gene duplication and insertion of a novel Ty1/copia-like retrotransposon in soybean. J Mol Evol 69, 164-175.

Kawase, M., Fukunaga, K., and Kato, K. (2005). Diverse origins of waxy foxtail millet crops in East and Southeast Asia mediated by multiple transposable element insertions. Mol Genet Genomics 274, 131-140.

Kazazian, H.H., Jr., Wong, C., Youssoufian, H., Scott, A.F., Phillips, D.G., and Antonarakis, S.E. (1988). Haemophilia A resulting from de novo insertion of L1 sequences represents a novel mechanism for mutation in man. Nature 332, 164-166.

Kikuchi, K., Terauchi, K., Wada, M., and Hirano, H.Y. (2003). The plant MITE mPing is mobilized in anther culture. Nature 421, 167-170.

Kinoshita, Y., Saze, H., Kinoshita, T., Miura, A., Soppe, W.J., Koornneef, M., and Kakutani, T. (2007). Control of FWA gene silencing in Arabidopsis thaliana by SINE-related direct repeats. Plant J 49, 38-45.

Kiyosawa, S. (1972). The inheritance of blast resistance transferred from some indica varieties in rice. Bull Nat Inst Agric Sci 23, 69-96.

Kobayashi, S., Goto-Yamamoto, N., and Hirochika, H. (2004). Retrotransposon-induced mutations in grape skin color. Science 304, 982.

Kunarso, G., Chia, N.-Y., Jeyakani, J., Hwang, C., Lu, X., Chan, Y.-S., Ng, H.-H., and Bourque, G. (2010). Transposable elements have rewired the core regulatory network of human embryonic stem cells. Nat Genet 42 , 631-634.

Lander, E.S., Linton, L.M., Birren, B., Nusbaum, C., Zody, M.C., Baldwin, J., Devon, K., Dewar, K., Doyle, M., FitzHugh, W., Funke, R., Gage, D., Harris, K., Heaford, A., Howland, J., Kann, L., Lehoczky, J., LeVine, R., McEwan, P., McKernan, K., Meldrim, J., Mesirov, J.P., Miranda, C., Morris, W., Naylor, J., Raymond, C., Rosetti, M., Santos, R., Sheridan, A., Sougnez, C., Stange-Thomann, N., Stojanovic, N., Subramanian, A., Wyman, D., Rogers, J., Sulston, J., Ainscough, R., Beck, S., Bentley, D., Burton, J., Clee, C., Carter, N., Coulson, A., Deadman, R., Deloukas, P., Dunham, A., Dunham, I., Durbin, R., French, L., Grafham, D., Gregory, S., Hubbard, T., Humphray, S., Hunt, A., Jones, M., Lloyd, C., McMurray, A., Matthews, L., Mercer, S., Milne, S., Mullikin, J.C., Mungall, A., Plumb, R., Ross, M., Shownkeen, R., Sims, S., Waterston, R.H., Wilson, R.K., Hillier, L.W., McPherson, J.D., Marra, M.A., Mardis, E.R., Fulton, L.A., Chinwalla, A.T., Pepin, K.H., Gish, W.R., Chissoe, S.L., Wendl, M.C., Delehaunty, K.D., Miner, T.L., Delehaunty, A., Kramer, J.B., Cook, L.L., Fulton, R.S., Johnson, D.L., Minx, P.J., Clifton, S.W., Hawkins, T., Branscomb, E., Predki, P., Richardson, P., Wenning, S., Slezak, T., Doggett, N., Cheng, J.F., Olsen, A., Lucas, S., Elkin, C., Uberbacher, E., Frazier, M., Gibbs, R.A., Muzny, D.M., Scherer, S.E., Bouck, J.B., Sodergren, E.J., Worley, K.C., Rives, C.M., Gorrell, J.H., Metzker, M.L., Naylor, S.L., Kucherlapati, R.S., Nelson, D.L., Weinstock, G.M., Sakaki, Y., Fujiyama, A., Hattori, M., Yada, T., Toyoda, A., Itoh, T., Kawagoe, C., Watanabe, H., Totoki, Y., Taylor, T., Weissenbach, J., Heilig, R., Saurin, W., Artiguenave, F., Brottier, P., Bruls, T., Pelletier, E., Robert, C., Wincker, P., Smith, D.R., Doucette-Stamm, L., Rubenfield, M., Weinstock, K., Lee, H.M., Dubois, J., Rosenthal, A., Platzer, M., Nyakatura, G., Taudien, S., Rump, A., Yang, H., Yu, J., Wang, J., Huang, G., Gu, J., Hood, L., Rowen, L., Madan, A., Qin, S., Davis, R.W., Federspiel, N.A., Abola, A.P., Proctor, M.J., Myers, R.M., Schmutz, J., Dickson, M., Grimwood, J., Cox, D.R., Olson, M.V., Kaul, R., Raymond, C., Shimizu, N., Kawasaki, K., Minoshima, S., Evans, G.A., Athanasiou, M., Schultz, R., Roe, B.A., Chen, F., Pan, H., Ramser, J., Lehrach, H., Reinhardt, R., McCombie, W.R., de la Bastide, M., Dedhia, N., Blocker, H., Hornischer, K., Nordsiek, G., Agarwala, R., Aravind, L., Bailey, J.A., Bateman, A., Batzoglou, S., Birney, E., Bork, P., Brown, D.G., Burge, C.B., Cerutti, L., Chen, H.C., Church, D., Clamp, M., Copley, R.R., Doerks, T., Eddy, S.R., Eichler, E.E., Furey, T.S., Galagan, J., Gilbert, J.G., Harmon, C., Hayashizaki, Y., Haussler, D., Hermjakob, H., Hokamp, K., Jang, W., Johnson, L.S., Jones, T.A., Kasif, S., Kaspryzk, A., Kennedy, S., Kent, W.J., Kitts, P., Koonin, E.V., Korf, I., Kulp, D., Lancet, D., Lowe, T.M., McLysaght, A., Mikkelsen, T., Moran, J.V., Mulder, N., Pollara, V.J., Ponting, C.P., Schuler, G., Schultz, J., Slater, G., Smit, A.F., Stupka, E., Szustakowski, J., Thierry-Mieg, D., Thierry-Mieg, J., Wagner, L., Wallis, J., Wheeler, R., Williams, A., Wolf, Y.I., Wolfe, K.H., Yang, S.P., Yeh, R.F., Collins, F., Guyer, M.S., Peterson, J., Felsenfeld, A., Wetterstrand, K.A., Patrinos, A., Morgan, M.J., de Jong, P., Catanese, J.J., Osoegawa, K., Shizuya, H., Choi, S., Chen, Y.J., and International Human Genome Sequencing, C. (2001). Initial sequencing and analysis of the human genome. Nature 409, 860-921. 
Levin, H.L., and Moran, J.V. (2011). Dynamic interactions between transposable elements and their hosts. Nat Rev Genet 12, 615-627.

Li, F., Fan, G., Lu, C., Xiao, G., Zou, C., Kohel, R.J., Ma, Z., Shang, H., Ma, X., Wu, J., Liang, X., Huang, G., Percy, R.G., Liu, K., Yang, W., Chen, W., Du, X., Shi, C., Yuan, Y., Ye, W., Liu, X., Zhang, X., Liu, W., Wei, H., Wei, S., Huang, G., Zhang, X., Zhu, S., Zhang, H., Sun, F., Wang, X., Liang, J., Wang, J., He, Q., Huang, L., Wang, J., Cui, J., Song, G., Wang, K., Xu, X., Yu, J.Z., Zhu, Y., and Yu, S. (2015). Genome sequence of cultivated Upland cotton (Gossypium hirsutum TM-1) provides insights into genome evolution. Nat Biotechnol 33, 524-530.

Li, F., Fan, G., Wang, K., Sun, F., Yuan, Y., Song, G., Li, Q., Ma, Z., Lu, C., Zou, C., Chen, W., Liang, X., Shang, H., Liu, W., Shi, C., Xiao, G., Gou, C., Ye, W., Xu, X., Zhang, X., Wei, H., Li, Z., Zhang, G., Wang, J., Liu, K., Kohel, R.J., Percy, R.G., Yu, J.Z., Zhu, Y.X., Wang, J., and $\mathrm{Yu}, \mathrm{S}$. (2014a). Genome sequence of the cultivated cotton Gossypium arboreum. Nat Genet 46, 567-572.

Li, Q., Xiao, G., and Zhu, Y.X. (2014b). Single-nucleotide resolution mapping of the Gossypium raimondii transcriptome reveals a new mechanism for alternative splicing of introns. Mol Plant 7, 829-840.

Li, X., Chen, L., Hong, M., Zhang, Y., Zu, F., Wen, J., Yi, B., Ma, C., Shen, J., Tu, J., and Fu, T. (2012). A large insertion in bHLH transcription factor BrTT8 resulting in yellow seed coat in Brassica rapa. PLoS One 7, e44145.

Lin, R., Ding, L., Casola, C., Ripoll, D.R., Feschotte, C., and Wang, H. (2007). Transposase-derived transcription factors regulate light signaling in Arabidopsis. Science 318, 1302-1305.

Lisch, D. (2009). Epigenetic regulation of transposable elements in plants. Annu Rev Plant Biol 60, 43-66.

Lisch, D. (2013). How important are transposons for plant evolution? Nat Rev Genet 14, 49-61.

Liu, B., Kanazawa, A., Matsumura, H., Takahashi, R., Harada, K., and Abe, J. (2008). Genetic redundancy in soybean photoresponses associated with duplication of the phytochrome A gene. Genetics 180, 995-1007.

Liu, J., He, Y., Amasino, R., and Chen, X. (2004). siRNAs targeting an intronic transposon in the regulation of natural flowering behavior in Arabidopsis. Genes Dev 18, 2873-2878.

Long, Q., Rabanal, F.A., Meng, D., Huber, C.D., Farlow, A., Platzer, A., Zhang, Q., Vilhjalmsson, B.J., Korte, A., Nizhynska, V., Voronin, V., Korte, P., Sedman, L., Mandakova, T., Lysak, M.A., Seren, U., Hellmann, I., and Nordborg, M. (2013). Massive genomic variation and strong selection in Arabidopsis thaliana lines from Sweden. Nat Genet 45, 884-890.

Magalhaes, J.V., Liu, J., Guimaraes, C.T., Lana, U.G., Alves, V.M., Wang, Y.H., Schaffert, R.E., Hoekenga, O.A., Pineros, M.A., Shaff, J.E., Klein, P.E., Carneiro, N.P., Coelho, C.M., Trick, H.N., and Kochian, L.V. (2007). A gene in the multidrug and toxic compound extrusion (MATE) family confers aluminum tolerance in sorghum. Nat Genet 39, 1156-1161.

Mao, H., Wang, H., Liu, S., Li, Z., Yang, X., Yan, J., Li, J., Tran, L.-S.P., and Qin, F. (2015). A transposable element in a NAC gene is associated with drought tolerance in maize seedlings. Nat Commun 6, 8326.

Martienssen, R. (2008). Great leap forward? Transposable elements, small interfering RNA and adaptive Lamarckian evolution. New Phytol 179, 570-572.

Martienssen, R., Barkan, A., Taylor, W.C., and Freeling, M. (1990). Somatically heritable switches in the DNA modification of Mu transposable elements monitored with a suppressible mutant in maize. Genes Dev 4, 331-343.

Martin, A., Troadec, C., Boualem, A., Rajab, M., Fernandez, R., Morin, H., Pitrat, M., Dogimont, C., and Bendahmane, A. (2009). A transposon-induced epigenetic change leads to sex determination in melon. Nature 461, 1135-1138.

McClintock, B. (1950). The origin and behavior of mutable loci in maize. Proc Natl Acad Sci USA 36, 344-355.
McClintock, B. (1951). Chromosome organization and genic expression. Cold Spring Harbor Symposia on Quantitative Biology 16, 13-47.

McClintock, B. (1984). The significance of responses of the genome to challenge. Science 226, 792-801.

McCue, A.D., Nuthikattu, S., Reeder, S.H., and Slotkin, R.K. (2012). Gene expression and stress response mediated by the epigenetic regulation of a transposable element small RNA. PLoS Genet 8, e1002474.

McCue, A.D., and Slotkin, R.K. (2012). Transposable element small RNAs as regulators of gene expression. Trends Genet 28, 616-623.

McDowell, J.M., and Meyers, B.C. (2013). A transposable element is domesticated for service in the plant immune system. Proc Natl Acad Sci USA $110,14821-14822$.

Michaels, S.D., He, Y., Scortecci, K.C., and Amasino, R.M. (2003). Attenuation of FLOWERING LOCUS C activity as a mechanism for the evolution of summer-annual flowering behavior in Arabidopsis. Proc Natl Acad Sci USA 100, 10102-10107.

Momose, M., Abe, Y., and Ozeki, Y. (2010). Miniature inverted-repeat transposable elements of Stowaway are active in potato. Genetics 186, 59-66.

Moon, S., Jung, K.H., Lee, D.E., Jiang, W.Z., Koh, H.J., Heu, M.H., Lee, D.S., Suh, H.S., and An, G. (2006). Identification of active transposon dTok, a member of the hAT family, in rice. Plant Cell Physiol 47, 1473-1483.

Muehlbauer, G.J., Bhau, B.S., Syed, N.H., Heinen, S., Cho, S., Marshall, D., Pateyron, S., Buisine, N., Chalhoub, B., and Flavell, A.J. (2006). A hAT superfamily transposase recruited by the cereal grass genome. Mol Genet Genomics 275, 553-563.

Naito, K., Cho, E., Yang, G., Campbell, M.A., Yano, K., Okumoto, Y., Tanisaka, T., and Wessler, S.R. (2006). Dramatic amplification of a rice transposable element during recent domestication. Proc Natl Acad Sci USA 103, 17620-17625.

Naito, K., Zhang, F., Tsukiyama, T., Saito, H., Hancock, C.N., Richardson, A.O., Okumoto, Y., Tanisaka, T., and Wessler, S.R. (2009). Unexpected consequences of a sudden and massive transposon amplification on rice gene expression. Nature 461, 1130-1134.

Nakayama, H., Afzal, M., and Okuno, K. (1998). Intraspecific differentiation and geographical distribution of Wx alleles for low amylose content in endosperm of foxtail millet, Setaria italica (L.) Beauv. Euphytica 102, 289-293.

Nakazaki, T., Okumoto, Y., Horibata, A., Yamahira, S., Teraishi, M., Nishida, H., Inoue, H., and Tanisaka, T. (2003). Mobilization of a transposon in the rice genome. Nature 421, 170-172.

Ong-Abdullah, M., Ordway, J.M., Jiang, N., Ooi, S.E., Kok, S.Y., Sarpan, N., Azimi, N., Hashim, A.T., Ishak, Z., Rosli, S.K., Malike, F.A., Bakar, N.A., Marjuni, M., Abdullah, N., Yaakub, Z., Amiruddin, M.D., Nookiah, R., Singh, R., Low, E.L., Chan, K.L., Azizi, N., Smith, S.W., Bacher, B., Budiman, M.A., Van Brunt, A., Wischmeyer, C., Beil, M., Hogan, M., Lakey, N., Lim, C.C., Arulandoo, X., Wong, C.K., Choo, C.N., Wong, W.C., Kwan, Y.Y., Alwee, S.S., Sambanthamurthi, R., and Martienssen, R.A. (2015). Loss of Karma transposon methylation underlies the mantled somaclonal variant of oil palm. Nature 525, 533-537

Park, K.I., Ishikawa, N., Morita, Y., Choi, J.D., Hoshino, A., and Iida, S. (2007). A bHLH regulatory gene in the common morning glory, Ipomoea purpurea, controls anthocyanin biosynthesis in flowers, proanthocyanidin and phytomelanin pigmentation in seeds, and seed trichome formation. Plant J 641-654.

Paszkowski, J. (2015). Epigenetics: the karma of oil palms. Nature 525, 466-467

Quadrana, L., Almeida, J., Asis, R., Duffy, T., Dominguez, P.G., Bermudez, L., Conti, G., Correa da Silva, J.V., Peralta, I.E., Colot, V., Asurmendi, S., Fernie, A.R., Rossi, M., and Carrari, F. (2014). Natural occurring epialleles determine vitamin $\mathrm{E}$ accumulation in tomato fruits. Nat Commun 5, 3027.

Ratcliffe, O.J., Amaya, I., Vincent, C.A., Rothstein, S., Carpenter, R., Coen, E.S., and Bradley, D.J. (1998). A common mechanism controls 
the life cycle and architecture of plants. Development 125, 1609-1615.

Rebollo, R., Romanish, M.T., and Mager, D.L. (2012). Transposable elements: an abundant and natural source of regulatory sequences for host genes. Annu Rev Genet 46, 21-42.

Salvi, S., Sponza, G., Morgante, M., Tomes, D., Niu, X., Fengler, K.A., Meeley, R., Ananiev, E.V., Svitashev, S., Bruggemann, E., Li, B., Hainey, C.F., Radovic, S., Zaina, G., Rafalski, J.A., Tingey, S.V., Miao, G.H., Phillips, R.L., and Tuberosa, R. (2007). Conserved noncoding genomic sequences associated with a flowering-time quantitative trait locus in maize. Proc Natl Acad Sci USA 104, 11376-11381.

Sano, Y. (1984). Differential regulation of waxy gene expression in rice endosperm. Theor Appl Genet 68, 467-473.

Saze, H., and Kakutani, T. (2007). Heritable epigenetic mutation of a transposon-flanked Arabidopsis gene due to lack of the chromatin-remodeling factor DDM1. EMBO J 26, 3641-3652.

Saze, H., Shiraishi, A., Miura, A., and Kakutani, T. (2008). Control of genic DNA methylation by a jmjC domain-containing protein in Arabidopsis thaliana. Science 319, 462-465.

Selinger, D.A., and Chandler, V.L. (2001). B-Bolivia, an allele of the maize b1 gene with variable expression, contains a high copy retrotransposon-related sequence immediately upstream. Plant Physiol 125, 1363-1379.

Singh, P., Bourque, G., Craig, N., Dubnau, J., Feschotte, C., Flasch, D., Gunderson, K., Malik, H., Moran, J., Peters, J., Slotkin, R., and Levin, H. (2014). Mobile genetic elements and genome evolution 2014. Mobile DNA 5, 26.

Slotkin, R.K., and Martienssen, R. (2007). Transposable elements and the epigenetic regulation of the genome. Nat Rev Genet 8, 272-285.

Slotkin, R.K., Nuthikattu, S., and Jiang, N. (2012). The impact of transposable elements on gene and genome evolution. In: Plant Genome Diversity. Vienna: Springer 35-58.

Smith, A.M. (1988). Major differences in isoforms of starch-branching enzyme between developing embryos of round- and wrinkled-seeded peas (Pisum sativum L.). Planta 175, 270-279.

Sommer, H., and Saedler, H. (1986). Structure of the chalcone synthase gene of Antirrhinum majus. Mol Gen Genet 202, 429-434.

Studer, A., Zhao, Q., Ross-Ibarra, J., and Doebley, J. (2011). Identification of a functional transposon insertion in the maize domestication gene tb1. Nat Genet 43, 1160-1163.

Tenaillon, M.I., Hollister, J.D., and Gaut, B.S. (2010). A triptych of the evolution of plant transposable elements. Trends Plant Sci 15, 471-478.

Tsuchiya, T., and Eulgem, T. (2013). An alternative polyadenylation mechanism coopted to the Arabidopsis RPP7 gene through intronic retrotransposon domestication. Proc Natl Acad Sci USA 110, E3535-E3543.

Tsugane, K., Maekawa, M., Takagi, K., Takahara, H., Qian, Q., Eun, C.H., and Iida, S. (2006). An active DNA transposon nDart causing leaf variegation and mutable dwarfism and its related elements in rice. Plant $\mathrm{J}$ 45, 46-57.

Uchiyama, T., Hiura, S., Ebinuma, I., Senda, M., Mikami, T., Martin, C., and Kishima, Y. (2013). A pair of transposons coordinately suppresses gene expression, independent of pathways mediated by siRNA in $\mathrm{An}$ tirrhinum. The New phytologist 197, 431-440.

van der Knaap, E., Sanyal, A., Jackson, S.A., and Tanksley, S.D. (2004). High-resolution fine mapping and fluorescence in situ hybridization analysis of sun, a locus controlling tomato fruit shape, reveals a region of the tomato genome prone to DNA rearrangements. Genetics 168 , 2127-2140.

Van Meter, M., Kashyap, M., Rezazadeh, S., Geneva, A.J., Morello, T.D., Seluanov, A., and Gorbunova, V. (2014). SIRT6 represses LINE1 retrotransposons by ribosylating KAP1 but this repression fails with stress and age. Nat Commun 5, 5011.

Varagona, M.J., Purugganan, M., and Wessler, S.R. (1992). Alternative splicing induced by insertion of retrotransposons into the maize waxy gene. Plant Cell 4, 811-820.

Wang, K., Huang, G., and Zhu, Y.X. (2016). Transposable elements play an important role during cotton genome evolution and fiber cell development. Sci China Life Sci doi: 10.1007/s11427-015-4928-y

Wang, K., Wang, Z., Li, F., Ye, W., Wang, J., Song, G., Yue, Z., Cong, L., Shang, H., Zhu, S., Zou, C., Li, Q., Yuan, Y., Lu, C., Wei, H., Gou, C., Zheng, Z., Yin, Y., Zhang, X., Liu, K., Wang, B., Song, C., Shi, N., Kohel, R.J., Percy, R.G., Yu, J.Z., Zhu, Y.X., Wang, J., and Yu, S. (2012). The draft genome of a diploid cotton Gossypium raimondii. Nat Genet 44, 1098-1103.

Wei, L., Gu, L., Song, X., Cui, X., Lu, Z., Zhou, M., Wang, L., Hu, F., Zhai, J., Meyers, B.C., and Cao, X. (2014). Dicer-like 3 produces transposable element-associated 24-nt siRNAs that control agricultural traits in rice. Proc Natl Acad Sci USA 111, 3877-3882.

Wessler, S.R. (1996). Turned on by stress. Plant retrotransposons. Curr Biol 6, 959-961.

Wessler, S.R., Baran, G., Varagona, M., and Dellaporta, S.L. (1986). Excision of Ds produces waxy proteins with a range of enzymatic activities. EMBO J 5, 2427-2432.

Woodhouse, M.R., Cheng, F., Pires, J.C., Lisch, D., Freeling, M., and Wang, X. (2014). Origin, inheritance, and gene regulatory consequences of genome dominance in polyploids. Proc Natl Acad Sci USA 111, 5283-5288.

Xiao, H., Jiang, N., Schaffner, E., Stockinger, E.J., and van der Knaap, E. (2008). A retrotransposon-mediated gene duplication underlies morphological variation of tomato fruit. Science 319, 1527-1530.

Xie, M., Hong, C., Zhang, B., Lowdon, R.F., Xing, X., Li, D., Zhou, X., Lee, H.J., Maire, C.L., Ligon, K.L., Gascard, P., Sigaroudinia, M., Tlsty, T.D., Kadlecek, T., Weiss, A., O'Geen, H., Farnham, P.J., Madden, P.A.F., Mungall, A.J., Tam, A., Kamoh, B., Cho, S., Moore, R., Hirst, M., Marra, M.A., Costello, J.F., and Wang, T. (2013). DNA hypomethylation within specific transposable element families associates with tissue-specific enhancer landscape. Nat Genet 45, 836-841.

Xue, W., Xing, Y., Weng, X., Zhao, Y., Tang, W., Wang, L., Zhou, H., Yu, S., Xu, C., Li, X., and Zhang, Q. (2008). Natural variation in Ghd7 is an important regulator of heading date and yield potential in rice. Nat Genet 40, 761-767.

Yan, Y., Zhang, Y., Yang, K., Sun, Z., Fu, Y., Chen, X., and Fang, R. (2011). Small RNAs from MITE-derived stem-loop precursors regulate abscisic acid signaling and abiotic stress responses in rice. Plant $\mathrm{J} 65$, 820-828.

Yang, Q., Li, Z., Li, W., Ku, L., Wang, C., Ye, J., Li, K., Yang, N., Li, Y., Zhong, T., Li, J., Chen, Y., Yan, J., Yang, X., and Xu, M. (2013). CACTA-like transposable element in ZmCCT attenuated photoperiod sensitivity and accelerated the postdomestication spread of maize. Proc Natl Acad Sci USA 110, 16969-16974.

Yao, J., Dong, Y., and Morris, B.A. (2001). Parthenocarpic apple fruit production conferred by transposon insertion mutations in a MADS-box transcription factor. Proc Natl Acad Sci USA 98, 1306-1311.

Yin, B.L., Guo, L., Zhang, D.F., Terzaghi, W., Wang, X.F., Liu, T.T., He, H., Cheng, Z.K., and Deng, X.W. (2008). Integration of cytological features with molecular and epigenetic properties of rice chromosome 4. Mol Plant 1, 816-829.

Zabala, G., and Vodkin, L. (2007). Novel exon combinations generated by alternative splicing of gene fragments mobilized by a CACTA transposon in Glycine max. BMC Plant Biol 7, 38.

Zabala, G., and Vodkin, L.O. (2005). The $w p$ mutation of Glycine max carries a gene-fragment-rich transposon of the CACTA superfamily. Plant Cell 17, 2619-2632.

Zemach, A., Kim, M.Y., Hsieh, P.H., Coleman-Derr, D., Eshed-Williams, L., Thao, K., Harmer, Stacey L., and Zilberman, D. (2013). The Arabidopsis nucleosome remodeler DDM1 Allows DNA methyltransferases to access H1-containing heterochromatin. Cell 153, 193-205.

Zeng, F., and Cheng, B. (2014). Transposable element insertion and epigenetic modification cause the multiallelic variation in the expression of FAE1 in Sinapis alba. Plant Cell 26, 2648-2659.

Zhai, J., Liu, J., Liu, B., Li, P., Meyers, B.C., Chen, X., and Cao, X. 
(2008). Small RNA-directed epigenetic natural variation in Arabidopsis thaliana. PLoS Genet 4, e1000056.

Zhang, J., Zhang, F., and Peterson, T. (2006). Transposition of reversed Ac element ends generates novel chimeric genes in maize. PLoS Genet 2, e164.

Zhang, P., Allen, W.B., Nagasawa, N., Ching, A.S., Heppard, E.P., Li, H., Hao, X., Li, X., Yang, X., Yan, J., Nagato, Y., Sakai, H., Shen, B., and Li, J. (2012). A transposable element insertion within ZmGE2 gene is associated with increase in embryo to endosperm ratio in maize. Theor Appl Genet 125, 1463-1471.

Zhang, T., Hu, Y., Jiang, W., Fang, L., Guan, X., Chen, J., Zhang, J., Saski, C.A., Scheffler, B.E., Stelly, D.M., Hulse-Kemp, A.M., Wan, Q., Liu, B., Liu, C., Wang, S., Pan, M., Wang, Y., Wang, D., Ye, W., Chang, L.,
Zhang, W., Song, Q., Kirkbride, R.C., Chen, X., Dennis, E., Llewellyn, D.J., Peterson, D.G., Thaxton, P., Jones, D.C., Wang, Q., Xu, X., Zhang, H., Wu, H., Zhou, L., Mei, G., Chen, S., Tian, Y., Xiang, D., Li, X., Ding, J., Zuo, Q., Tao, L., Liu, Y., Li, J., Lin, Y., Hui, Y., Cao, Z., Cai, C., Zhu, X., Jiang, Z., Zhou, B., Guo, W., Li, R., and Chen, Z.J. (2015a). Sequencing of allotetraploid cotton (Gossypium hirsutum L. acc. TM-1) provides a resource for fiber improvement. Nat Biotechnol $33,531-537$.

Zhang, X. (2008). The epigenetic landscape of plants. Science 320, 489-492.

Zhang, X., Sun, J., Cao, X., and Song, X. (2015b). Epigenetic mutation of RAV6 affects leaf angle and seed size in rice. Plant Physiol 169, 2118-2128. 